\title{
SCIENCE EDUCATION FOR BLIND AND VISUALLY IMPAIRED CHILDREN
}

\author{
Janja Plazar ${ }^{1}$, Cécil J. W. Meulenberg ${ }^{2}$, Aksinja Kermauner ${ }^{1}$ \\ ${ }^{1}$ Faculty of Education, University of Primorska, Koper, Slovenia \\ ${ }^{2}$ Science and Research Centre Koper, Koper, Slovenia \\ janja.plazar@upr.si; cecil.meulenberg@zrs-kp.si; aksinja.kermauner@upr.si
}

Received: 16 January 2021

\begin{abstract}
Nowadays, science education is based predominantly on the principle of constructivism, according to which children should be active participants in the learning process and construct their knowledge based on experience. For blind or visually impaired children, science education methods and educational tools must be adapted according to their perceptual needs, in order for these children to be active participants in the learning process. The aim of the current paper is to describe the latest view on active and inquiry-based learning in science education for blind or visually impaired children while simultaneously minimizing misconceptions. Further, the paper compiles the recent research that enables prosperous and high-quality adaptive educational approaches and tools. Thus, the content of this paper will be useful for both science teachers and researchers of inclusive classrooms.
\end{abstract}

Keywords: active learning, adjusted educational tools, blindness, inclusion, visual impairment

\section{Introduction}

Science education for pre-school and primary school children requires skilled teachers and continuous training of teachers and teaching educators. It is important for science to be correctly transferred to children from an early age (Trundle, 2010), as it will provide them with important information to understand their natural surroundings, while being fundamental to future academic and professional skills (Saçkes et al., 2011), simultaneously reducing the incidence of misconceptions 
(Briten, Allen, 2018). Therefore, early science education is considered crucial in most of the educational programmes. In the process of learning, children mostly rely on information, which they get through their sense of vision and this remains a crucial sensory pillar of pedagogy throughout the European educational systems. With the development of inclusion, blind and visually impaired children introduced special needs in regular schools, as they are entitled to accomplish learning goals in mainstream schools based on an inclusive paradigm (Kumar et al., 2001). Consequently, science teachers in inclusive classes need to develop different adaptations and strategies to teach science, where students can use other senses than vision (Martin et al., 2014). Subsequently, also typical visually-developed peers in the inclusive classrooms can benefit from this, as research shows that teachers in inclusive science classes with teaching adaptations actively improve their methods for all students (Rule et al., 2011).

The following paper aims to describe the current view on inclusive science education for blind and visually impaired children. Based on identified relevant literature, first, we explain the importance of science education in the early years, and the effective approaches to teach science to children. Then we introduce the incidence and categorisation of blindness and visual impairments; clarify their corresponding world perception and general inclusive teaching while indicating the importance of science education in the early years of development. Next, we describe the most effective teaching approaches with specific attention to active involvement and the use of adapted methods and tools. In the final section, we review effective examples of adaptations for blind or visually impaired children in the science class.

\section{Research methodology}

The search strategy and literature selection process followed the protocol, preferred for reporting on systematic reviews. From May 2019 to June 2020, the following databases were searched: PubMed Medical Information System, EBSCO host, Web of Science, Google Scholar database, the Slovenian Co-operative Online Bibliographic System, and Services-catalogue database (COBISS.SI), using the following keywords: 'blind', 'blindness', 'visual impairment', 'preschool', 'primary 
school', 'adapted educational tools', 'adapted methods', 'science education', 'science teachers'.

Titles, abstracts and content were reviewed for scientific and technical research in the field of science education for blind and/or visual impaired children, and inappropriate and repetitive papers were eliminated. The total number of initial search results was 5 813. After excluding duplicates and considering the content, 90 articles, books and book chapters remained for further analysis. The most interesting scientific and professional contributions were selected. Although some of the relevant selected articles are already 45 years old, the selection of final publications predominantly describes research, published in the last 20 years, which are presented in the form of a descriptive review of relevant domestic and foreign professional and scientific literature, of which the content is compiled and divided into chapters, dealing with the most important research.

\section{Science education in the early years}

\section{The importance of science education}

From an early age, children have an instinctive natural need to observe, think and explore nature and events, look for answers and questions, and understand primary science-related concepts. Therefore, learning science in children starts in pre-school, when they develop a basic understanding of natural phenomena and processes through everyday activities, e.g., playing with sand, blowing soap bubbles, using a light source and making shadows, collecting and observing stones, shells, earthworms and other garden plants and animals (Conezio, French, 2002; Katalinič, 2010; Mantzicopoulos et al., 2008; Trundle, 2010; Tu, 2006). By playing, children observe and imitate natural phenomena from their environment, and gain their first insights into the world of science. The basic understanding of nature that children acquire through their own experiences is a good basis for understanding more complex phenomena and processes in the later stages of cognitive development (Eshach, Fried, 2005). Environmental influences are extremely important in early childhood; a lack of environmental stimuli can even lead to a child's development not reaching its full potential (Hadzigeorgiou, 2002; Trundle, 2010). 
However, it is not enough to expose oneself to natural phenomena and observe nature only in the pre-school period. In order to develop a positive attitude towards science and to help children to understand the world, gather and organize information, and apply and test new ideas, it is essential to offer a combination of: guidance by experienced and qualified adults, a stimulating and engaging environment, and a good science education program (Tu, 2006). Such a combination leads to all students acquiring a solid foundation of basic scientific knowledge and skills. Importantly, this includes a coherent, well-designed curriculum, teachers who have the resources and skills to teach effectively, and communities and families committed to excellence (Mirzaie et al., 2009; Tu, 2006).

Early science learning at pre-school age helps to develop a positive attitude towards science, besides, fosters the ability to grasp abstract ideas and discover nature while solving problems in a logical and scientific way (Eshach, Fried, 2005; Krnel, 2008). Consequently, children's ideas about scientific concepts are often extremely stable. However, poor and subject-related misrepresentation of scientific content in early childhood can lead to negative attitudes towards science and misconceptions that can persist up to high-school and beyond (Mullis, Jenkins, 1988). Once embedded, these are very difficult to refute. Even when science teachers offer counter-evidence, it might be ignored, rejected, or the earlier interpretation will remain (Trundle, 2014). The contents of such misconceptions make sense to children, but can confuse once the alternative - scientifically correct - explanations, are presented later in class (Briten, Allen, 2018). In early science education it is therefore important that scientific concepts are presented to children by a competent teacher in a simple, yet scientifically correct way, using didactic approaches that reduce the incidence of misconceptions.

\section{Effective approaches of science education in preschool and primary school period}

The traditional way of teaching science, in which a teacher plays an active role in the classroom and students listen passively, has been replaced in recent decades by modern didactic approaches (SkribeDimec, 2009; Trundle, 2010), predominantly the constructivist phi- 
losophy. This approach implies that learning is not a passive acquisition of knowledge, skills and habits, but a progressive transformation of the individuals, incorporating their own activity, combining existing knowledge with a new one (Ferjan, 2005; Ivanuš Grmek et al., 2009). Children act as active participants in the learning process and build construct - their knowledge through their own experiences and mental activity (Gil-Pérez et al., 2002; Mastropieri et al., 2001; Trundle, 2010). It therefore requires students to be mentally, physically and socially active and to rebuild knowledge through their own understanding (Marentič Požarnik, 2020), and reconnect already existing cognitive structures with the newly acquired knowledge, thus upgrading and rearranging. In this way, the student's incorrect, naive and incomplete ideas about natural processes and phenomena can be rebuilt, and false ideas can be more easily replaced by correct ones later in life (Marentič Požarnik, 2003).

An important didactic approach, based on the principles of constructivism, is inquiry-based learning (Marentič Požarnik, 2020). The central idea of the "guided inquiry"-approach is that the individual acquires knowledge through his/her own experience when actively involved in the learning process. Besides, it strengthens the children's sense of work responsibility and increases their motivation. This approach promotes active learning by including practical activities in small groups, where children and teachers have more opportunities to exchange views, discuss and cooperate, that enhance mutual respect, tolerance and attitudes inherent to science education (Alveirinho et al., 2017; Barell, 2007; Ivanuš Grmek et al., 2009; Trundle, 2010). Such an experiential environment creates more opportunities to form correct scientific concepts (Trundle, 2010), and in addition, maintains children's curiosity and ongoing interest in knowledge, and develops skills necessary for independent problem solving (Petek, 2012).

\section{Blindness and visual impairments}

\section{Incidence and categorisation of visual impairments}

Vision is considered the most important sense in today's visually oriented society (Kermauner, 2011; Kermauner, 2014a; Mitchell, 1986), 
as through vision humans receive up to $83 \%$ of all worldly information. The remaining $17 \%$ of information reaches our brains through the other senses: $11 \%$ via hearing, 3,5\% via smell, 1,5\% via the sense of touch, and only $1 \%$ via taste (Stolovitch, Keeps, 2014). In light of this paradigm, blindness within our society is a severe sensory disability.

According to the latest statistics from the World Health Organization (WHO, 2019), there are 2,2 billion people worldwide blind or visually impaired, including 19 million children under the age of fifteen.

Blindness and visual impairment cover a whole spectrum of disorders and problems of vision. Generally, vision impairment refers to a reduced ability to see, usually caused by an illness, injury or eye disease immediately after birth (Eškirović, 2015), it can be a decrease in visual acuity, decreased visual field, problems with colour discrimination, and lack of binocular vision. Importantly, the functional ability of blind or visually impaired children is not only caused by the impairment itself, but by a number of additional elements of their biopsychosocial structures. Consequently, the demographic properties of these children are extremely heterogeneous and vary greatly in terms of perceptual functions, cognitive abilities, motor skills and behaviour (Cain, Fanshawe, 2019). This heterogeneity is caused by a number of circumstances and their interaction - the subculture of visual impairment, dispositions, environment, self-activity and the possible presence of other disorders (Kermauner, 2011). In Table 1, the classification of visual impairment according to international criteria as stated by the World Health Organisation (WHO, 2021) is summarized and supplemented by the criteria of American Optometric Association (2021) and of National Eye Institute of the National Institutes of Health, USA (2020).

Table 1. Categories of visual impairment based on World Health Organisation classification (WHO, 2021) and on classification of American Optometric Association (2021) and of National Eye Institute of the National Institutes of Health, USA (2020).

\begin{tabular}{|l|l|c|}
\hline \multicolumn{1}{|c|}{$\begin{array}{c}\text { Categories of visual } \\
\text { impairment }\end{array}$} & \multicolumn{1}{|c|}{ Visual acuity } & \multicolumn{1}{c|}{$\begin{array}{c}\text { Central field } \\
\text { vision** }\end{array}$} \\
\hline $\begin{array}{l}\text { Low vision } \\
\text { I. moderate }\end{array}$ & $\begin{array}{l}5 \%-30 \% \\
10 \%-30 \%(6 / 18-6 / 60)\end{array}$ & \\
II. severe & $5 \%-10 \%(6 / 60-3 / 60)$ & $10^{\circ}-20^{\circ}$ \\
\hline
\end{tabular}




\begin{tabular}{|l|l|l|}
\hline $\begin{array}{l}\text { Blindness } \\
\text { III. with residual vision } \\
\text { IV. With minimal visual } \\
\text { abilities } \\
\text { V. total }\end{array}$ & $\begin{array}{l}<5 \% \\
2 \%-5 \%(3 / 60-1 / 60) \\
\text { Light perception and/ or } \\
\text { light projection to }<2 \% \\
\text { No light and form } \\
\text { perception and projection } \\
\text { (amaurosis) }\end{array}$ & $\begin{array}{l}<5^{\circ}-10^{\circ} \\
\text { Cortical visual } \\
\text { impairment }\end{array}$ \\
$\begin{array}{l}\text { Visual impairment, where visual problems } \\
\text { are primarily caused by neurological } \\
\text { problems or brain damage (as compared to } \\
\text { visual impairment and blindness where the } \\
\text { primary causes are the eyes and its nerve } \\
\text { pathways) } \\
\text { Problems with visual attention and visual } \\
\text { complexity, visual and fixation disturbances, } \\
\text { and signs of delayed, slow, or atypical visual } \\
\text { response. }\end{array}$ \\
\hline
\end{tabular}

*regardless of visual acuity

\section{Perception of the world by blind and/or visually impaired children}

For most people, visual abilities enable them to move and live independently in the world, and to read, write, draw, observe, measure and perceive natural phenomena. Children who are blind or visually impaired have difficulties in perceiving the world around them (Horzum, 2018). Their ideas about natural phenomena and complex changes in nature are often incomplete or even wrong. Problems also occur in the perception of distances, directions and relations between objects in space, in orientation in micro and macro space (Brvar, 2000; Horzum, 2018). In general, the perception of an object, or phenomenon, is gradual and develops during childhood. While already limited in these, in addition, a blind child recognizes and perceives an object from his or her surroundings mostly by touch. Other senses are also a source of information, but the dominant sense is the sense of touch and tactile communication (Milković, Šupe, 2013) which is a proximal sense and 
therefore has significant limitations in learning about the child's environment (Kermauner, 2014a).

In early childhood, for blind or visually impaired children the motivation to explore the environment can be stimulated by early treatment and perceptual exercises. As long as a blind or visually impaired child has access to suitable toys, materials, aids, adapted methodological procedures and educational tools that help overcome the deficit, he/she can equal sighted peers in knowledge (Brvar, 2010).

\section{General teaching for blind and/or visually impaired students}

In teaching, it should be ensured that blind or visually impaired students retain sensory images of objects as long as possible over the early educational lifespan, as this is the basis for the development of their cognitive skills (Rosenblum et al., 2018). In addition, as inclusion developed, children with blindness or visual impairment became part of the regular school process, usually labelled as one of the groups of children with special needs, still achieving similar learning goals as typical visually-developed children (Kumar et al., 2001).

In order to successfully teach blind or visually impaired students, teachers need to acquire basic knowledge and skills related to: (1) the adaptation of the learning content; (2) the assessment of students with special needs; (3) the use of assistive technology; and (4) the individualization of the learning process (Štemberger, 2013). The teacher must also have access to an appropriate number of special aids and educational tools. It is also recommended that on the basis of the abilities and characteristics of a blind or visually impaired student, the teacher divides the teaching content into smaller units and regularly re-assesses whether the student truly understands the subject matter, pays attention to all steps of the cognitive process, and gives priority to multimodal forms of teaching and considers different ways of presenting knowledge. If, however, despite all adjustments, knowledge gaps, lack of motivation or poor organization of learning occur, it is necessary to involve additional professional help, like special inclusive educators (Florjančič et al., 2003). 
When teaching a blind or visually impaired student, the teacher must follow certain methodological and didactic principles: (1) loud and clear speech, (2) the student should always be close enough; (3) the student should be able to look closely at the blackboard or educational tools; (4) in the experiments, the student needs the opportunity to be in the foreground while at the same time hear detailed description of the procedures in process; (5) the presentation of the teaching contents should preferably refer to nature, in the form of walks and excursions, where visually impaired students are additionally informed about smaller objects and the blind students are additionally given expressive descriptions of the environment and natural phenomena (next to the pupil's sensing abilities); and, finally, (6) the teacher must always ensure safety (Martin et al., 2014).

In addition, the teacher must be well acquainted with the primary school curricula for an adapted educational program with an equivalent educational standard for blind and visually impaired students (Republic of Slovenia, Ministry of education, 2011), where, compared to the general curricula for teaching in regular primary schools, the objectives and knowledge standards remain the same, and adaptations are made only at the level of specific didactic recommendations (Plazar, 2015). Thus, the teaching and didactic material must be adapted accordingly to the visual ability of the individual student, and therefore it is necessary that the teacher is familiar with visual acuity, diagnosis, perceptual characteristics etc. of the student. In addition, the teacher must also take into account the other senses and should introduce multisensory learning. And while the student must be proficient in all the contents of the curriculum, for some, like geometry and measurements in mathematics and physics, the teacher cannot expect accuracy (Florjančič et al., 2003), and thus encourages and motivates, but should help the student only as much as is needed (Brvar, 2010). 


\section{Teaching science to children with blindness and/or visual impairments}

\section{Active involvement in science classes}

Many researchers and educators believe that science is an important area for students with special needs (Mastropieri, Scruggs, 1992; Norman et al., 1998), and therefore also for students with blindness or visual impairments. By learning science, children not only acquire scientific knowledge and are educated in science, but also discover their own abilities, learn to work in groups, train their skills and develop positive personality traits (Erwin et al., 2001; Norman et al., 1998). In addition, knowledge of sciences enables a better understanding of the world and stimulates children's curiosities and interests, as it provides knowledge for understanding complex relationships in nature (Erwin et al., 2001; Kavkler, 2005; Norman et al., 1998). In the past, learning science was often inaccessible to blind or visually impaired children, and was neglected because teaching from different fields of science relied on information and ideas based on traditional teaching in the form of lectures, which were mainly based on visual presentations (Rosenblum et al., 2019; Sahin, Yorek, 2009; Therrien et al., 2014). As all children are capable of learning science, teachers need to create an appropriate learning environment (Kavkler, 2005; Martin et al., 2014). However, studies show that most science teachers have insufficient knowledge and experience to teach children with special needs and very few special-needs-teachers are trained to teach science (Norman et al., 1998; Plazar, 2015). Thus, students with special needs in science education do not receive appropriate materials and instructions, rarely receive practical work, active learning and go on excursion, and as a result for science education blind or visually impaired students lag behind their sighted peers (Kumar et al., 2001). In general, the practical activities experienced by blind or visually impaired students are simple, not demanding enough, and therefore do not pose an intellectual challenge to the students (Fraser, Maguvhe, 2008). Prospective science teachers should therefore ensure that blind or visually impaired children can also actively participate in science lessons in an inclusive class (Kumar et al., 2001; Maroney et al., 2003; Martin et al., 2014), while they also 
should be trained in the use of resource materials and adaptive technologies (Kumar et al., 2001).

Kolenc (2005) points out that a science teacher in an inclusive classroom should be attentive to include: (1) different and interesting experiences, where success does not depend only on understanding the theoretical knowledge, (2) as much practical work as possible adapted to the child's abilities and skills, (3) tasks with different levels of difficulty, which allow good performance even for children with special needs, and (4) tasks where performance does not depend only on previously acquired knowledge and language skills.

Teaching blind or visually impaired children can be a particular challenge for a teacher. With high quality methods and support, such as adaptation of didactic tools and a certain degree of individualized teaching, such a student can be fully involved in a science class and participate easily in the inclusive learning process (Dion et al., 2000; Martin et al., 2014).

\section{Adaptations of educational approaches and tools}

In educating blind or visually impaired children it is necessary to develop different methods, tools, approaches and ways to achieve the same learning standards (Kizilaslan et al., 2019; Mulloy et al., 2014). It is necessary to find or create alternative information for objects or concepts in the curriculum from the environment, that are within reach of the child's perception and to adapt the visual and graphic material accordingly. Didactic material must be adapted so that students can effectively use their vision or other senses, especially touch and hearing (Kermauner, 2014b; Martin et al., 2014). For blind students audio-tapes should be used and for visually impaired students enlarged printed materials must be clear, in good contrast, with bright colours and without too many geometric designs (Martin et al., 2014): models and reliefs must be clear and generalized with simple shapes. Appropriate sizes and correct proportions are extremely important, but should omit unnecessary details that might disturb tactile or reduced visual perception. Besides, the material from which they are made must also be haptically similar to the real image of an object or concept (Kermauner, 2004; Martin et al., 2014). In science class while experiential and kinaesthetic 
learning, the 3-D models, auditory instructions, talking science equipment, should preferably follow all these rules (Rosenblum et al., 2019).

When learning science, attention must also be paid to the clarity of the procedure for conducting various scientific experiments. In order for the students to be actively involved in the experiment, they must concentrate well on it. The tutor who accompanies the blind or visually impaired student during the execution of the experiment, uses clear and understandable verbal communication, asks simple and clear questions about the course of the experiment, helps to sense certain elements of the experiment, and assists with the spatial orientation, the arrangement of elements and objects (Martin et al., 2014; Rosenblum et al., 2019). Furthermore, Wild and Koehler (2017) state that additional responsibilities of a science teacher in supporting students in inclusive classrooms are to: teach prerequisite skills to students prior to science topics being covered in class, assess and address any misconceptions students have about science topics, and co-teach or work in small groups that enable to model accessible teaching techniques for teachers and students.

\section{Examples of active participation using adapted tools}

The literature shows that a considerable number of studies have been conducted involving these students in the active learning of science, especially in the lower grades of primary school (Beck-Winchatz, Ostro, 2004; Beck-Winchatz, Riccobono, 2008; Jones et al., 2006; Wagner, 1995). However, research and experiments on the integration of blind or visually impaired students have been prepared and evaluated mainly in the upper classes of primary, secondary and higher education (Azevedo et al., 2014; Kizilaslan et al., 2019; De Oliveira et al., 2017; Weems, 1977): typically in biochemistry, chemistry and physics classes, during which teachers or university professors, with the help of special education teachers have adapted experimental work (Kumar et al., 2001; Sahin, Yorek, 2009).

Unfortunately, several studies report that in schools it is common practice that blind students are not allowed to conduct experiments in the classroom or in the laboratory, but are instead paired with sighted peers who take over the tasks and share the information about the ongoing experiment (Reynaga-Peña, López-Suero, 2020). However, in a 
recent review article, the authors examined several researches conducted between 2009 and 2018, and claim that all students with blindness or visual impairment can learn scientific content, if they have access to adapted educational tools and if teachers adapt science lessons accordingly, because they have cognitive abilities identical to typical visually-developed peers (Ediyanto, Kawai, 2019). Moreover, many studies reveal that adaptations, which were provided for students with visual impairment, benefitted the entire class (Rule et al., 2011), where adapted educational tools and teaching strategies were not good only for the students with visual impairments, but equally good for other students as well (Kermauner, Plazar, 2019; Koomen et al., 2018; Stefanich, 2018).

The next section reviews successful practical implementations of adapted science teaching to students with blindness or visual impairments (summarized in Table 2).

The first researches and reports on the inclusion of students with blindness or visual impairment in regular science lessons date back to the 1970s. Weems (1977) describes the Optacon device, which transferred information from the screens of digital instruments used in physics experiments, into tactile information on the screen surface of a blind student's, similar to the Braille principle. Baughman and Zollman (1977) report about an experimental work with a student of physics with congenital blindness who, with the help of adaptations of simple technical aids such as a bar, scales, measuring cups and a board, was able to easily reproduce physical experiments and perform them together with his sighted classmates.

Wagner (1995) also describes the adaptation of devices for measuring length in physics lessons for a blind pupil, who marked every centimetre with a stapler or glue that the pupil could touch and feel. A similar device for measuring length is described by Windelborn (1999), who, in addition to a measuring stick, created an electrical circuit for a blind student and an adapted board for entering results, based on which a student drew a graph with pins. A more recent case study in the field of physics education for visually impaired students in primary schools, reports on the adaptation of educational tools in dealing with the conversion of electricity into light. Prior to adapting the teaching, the general and special needs of seven visually impaired students were identified, and on this basis the adapted didactic tools were developed 
to help all students enrolled in science teaching to understand the selected physics content (Okcu, Sozbilir, 2019). Azevedo et al. (2014) described adapted physical experiments in the field of optics in which teachers use a laser to explain the phenomenon of refraction and reflection of light to blind students. The students use thermo receptors to detect a change in temperature at the point on the skin where the laser beam is positioned. From this they draw conclusions about the course of the light rays. Since to most primary and secondary school students astronomy is of interest, and also to the ones who are blind or visually impaired, such educational tools, adapted and prepared to understand space-related content, are of crucial importance. They have the potential to explain the objects and dimensions in space that are too large to be compared with known objects and dimensions on Earth. In presenting this content, teachers used 2-D and 3-D models of the solar system and galaxies (Beck-Winchatz, Ostro, 2004) and tactile books with astronomy content (Beck-Winchatz, Riccobono, 2008).

In addition, various studies report on adjustments of chemistry teaching methods and didactic tools for blind and visually impaired students in primary and secondary schools and universities. For the teaching of chemistry in primary school, Hasse and colleagues (2011) proposed a removable black and white model of the atom, which helps both visual impaired and blind students, due to the model's contrast and relief structure, respectively. Adaptations, related to chemistry teaching in an observation-based laboratory are more difficult to implement, because the safety of blind or visually impaired students needs to be guaranteed. Most authors see computer-based tools and synthetically spoken laboratory equipment as a solution that would help blind or visually impaired students to understand the procedures and results of chemical experiments (Kumar et al., 2001; Nepomuceno et al., 2016; Supalo et $a l ., 2007)$. One of the most recent studies focuses on the adaptation of didactic illustrations for blind students for the topic "Energy in living systems" (Teke, Sozbilir, 2019). In their work, the authors highlight the adaptation of different molecule structures into tactile forms. Based on the observations and conversations with the student, the teachers created educational tools that helped the student to understand both the structures of different molecules and, besides, the principle of energy transfer. 
Also in the study of Kizilaslan et al. (2019) an activity was designed to teach the insulation properties of different materials to visually impaired or blind students, in which different everyday materials were used to familiarize students with the concepts of thermal conductivity and the importance of thermal-insulation materials.

In the study of biochemistry, the concepts are often very abstract and based on visual representations. De Oliveira and colleagues (2017) developed a series of experiments and graphic representations that enabled biochemistry students to understand the properties of enzymes, using samples of different viscosity and graphics made of cold porcelain with Braille labels.

Similar to astronomy, biology encounters objects that cannot be truly touched and felt. While in astronomy lessons with unimaginably large objects, in contrast to biology lessons, objects are too small to touch to comprehend their structure. One example are the cells of animals and plants with their cellular organelles, which can only be explained to blind or visually impaired students using 2-D and 3-D models (Jones et al., 2006): cell division can be shown using chromosome models with additional tactile markers, as well as the recombination in the process of meiosis (Ricker, Rodgers, 1981). Recently, the study of the use of specially-adapted digital dichotomous identification keys to identify plants was investigated and yielded a new innovative botanical education tool that contributed significantly to the knowledge of plant identification by blind botany students (Andjić et al., 2019).

Table 2. Overview of studies reporting adapted science educational tools for active participation of blind or visually impaired students.

\begin{tabular}{|l|l|l|}
\hline $\begin{array}{c}\text { Authors of } \\
\text { the study } \\
\text { (publication year) }\end{array}$ & \multicolumn{1}{|c|}{$\begin{array}{c}\text { Science } \\
\text { field }\end{array}$} & \multicolumn{1}{|c|}{$\begin{array}{c}\text { Short description of the } \\
\text { adapted tool }\end{array}$} \\
\hline $\begin{array}{l}\text { Andjić } \text { et al. } \\
(2019)\end{array}$ & botany & plant identification for blind \\
\hline $\begin{array}{l}\text { Azevedo } \text { et al. } \\
(2014)\end{array}$ & physics & $\begin{array}{l}\text { explanation of reflection and } \\
\text { refraction of light rays, using laser } \\
\text { beams positioned on students' skin }\end{array}$ \\
\hline
\end{tabular}




\begin{tabular}{|l|l|l|}
\hline $\begin{array}{l}\text { Baughman and } \\
\text { Zollman (1977) }\end{array}$ & physics & $\begin{array}{l}\text { performing experiments with } \\
\text { adaptation of simple technical aids } \\
\text { (bars, scales, measuring cups and a } \\
\text { board) }\end{array}$ \\
\hline $\begin{array}{l}\text { Beck-Winchatz } \\
\text { and Ostro (2004) }\end{array}$ & astronomy & $\begin{array}{l}\text { 2D/3D models of the solar system and } \\
\text { galaxies }\end{array}$ \\
\hline $\begin{array}{l}\text { Beck-Winchatz } \\
\text { and Riccobono } \\
(2008)\end{array}$ & astronomy & tactile books with astronomy content \\
\hline $\begin{array}{l}\text { De Oliveira } \text { et al. } \\
(2017)\end{array}$ & biochemistry & $\begin{array}{l}\text { graphic representations made of cold } \\
\text { porcelain and different viscosity } \\
\text { samples, for understanding enzyme } \\
\text { properties }\end{array}$ \\
\hline Hasse et al. (2011) & chemistry & $\begin{array}{l}\text { model of the atom, using black and } \\
\text { white contrasts }\end{array}$ \\
\hline Jones et al. (2006) & cell biology & $\begin{array}{l}\text { 2D/3D models of animal and plant } \\
\text { cells with organelles }\end{array}$ \\
\hline $\begin{array}{l}\text { Kizilaslan } \text { et al. } \\
(2019)\end{array}$ & physics & $\begin{array}{l}\text { thermal conductivity and isolation } \\
\text { properties of materials }\end{array}$ \\
\hline $\begin{array}{l}\text { Kumar } \text { et al. } \\
(2001)\end{array}$ & chemistry & $\begin{array}{l}\text { computer-based tools and } \\
\text { synthetically spoken laboratory } \\
\text { equipment }\end{array}$ \\
\hline $\begin{array}{l}\text { Nepomuceno } \text { et al. } \\
(2016)\end{array}$ & chemistry & $\begin{array}{l}\text { computer-based tools and } \\
\text { synthetically spoken laboratory } \\
\text { equipment }\end{array}$ \\
\hline $\begin{array}{l}\text { Okcu and Sozbilir } \\
(2019)\end{array}$ & physics & $\begin{array}{l}\text { adapted didactic tools that convert } \\
\text { electricity into light }\end{array}$ \\
\hline $\begin{array}{l}\text { Ricker and } \\
\text { Rodgers (1981) } \\
(2007)\end{array}$ & cell biology & $\begin{array}{l}\text { tactile models that demonstrate } \\
\text { chromosomes and recombination } \\
\text { during meiosis }\end{array}$ \\
\hline $\begin{array}{l}\text { Teke and Sozbilir } \\
\text { col9) }\end{array}$ & chemistry & $\begin{array}{l}\text { tactile models of different molecules } \\
\text { for understanding the principle of } \\
\text { energy transfer in living systems }\end{array}$ \\
\hline equipment spoken laboratory \\
\hline
\end{tabular}




\begin{tabular}{|l|l|l|}
\hline Wagner (1995) & physics & $\begin{array}{l}\text { measuring length: marking } \\
\text { centimetres with a stapler/glue }\end{array}$ \\
\hline Weems (1977) & physics & $\begin{array}{l}\text { experiments and device that transfers } \\
\text { digital information from instruments } \\
\text { to tactile information (Optacon } \\
\text { device) }\end{array}$ \\
\hline Windelborn (1999) & physics & $\begin{array}{l}\text { adapted measuring stick: an electrical } \\
\text { circuit and a board to draw a graph } \\
\text { with pins }\end{array}$ \\
\hline
\end{tabular}

\section{Conclusions}

The current review describes the importance of science education for blind and visually impaired students, especially for better understanding their surroundings. The research describes adapted tools and methods of teaching science on different educational levels, but in order to be effective, science educators needs to include specific attention and active involvement of students. Worldwide research suggests that the inclusion of these students in science lessons is possible and useful. However, this requires qualified teachers with the skills and knowledge to teach children with blindness or visual impairments in inclusive classrooms. Appropriately trained teachers, with the help of special education teachers, can easily adjust teaching methods and adapt educational tools. Interestingly, from our own experience and from the other research findings cited in this paper, it must be emphasized that all the adaptations are often well received by both groups of students: typical visually-developed and the blind or visually impaired ones. Thus, blind or visually impaired students can be included in science lessons at all levels of education in regular schools, and can be supported to acquire scientific knowledge actively and without misconceptions, enabling them to have successful and high-quality education. 


\section{Bibliography}

Alveirinho, Dolores; Bento, Júlia; Nunes, Manuel (2017), “The science experiment and the playful learning: Window of opportunity for curricular articulation in the transition between preschool education and primary education", ICERI2017 Proceedings, pp. 8629-8635.

American Optometric Association (AOA) (2021), Low Vision and Vision Rehabilitation. Available at: https://www.aoa.org/healthy-eyes/caring-for-your-eyes/ low-vision-and-vision-rehab?sso=y [29 April 2021]

Andjić, Branko; Cvijetićanin, Stanko; Hayhoe, Simon; Grujičić, Rade; Stešević, Danijela (2019), "Dichotomous keys in the botanical learning of non-visual (blind) people", Journal of Baltic Science Education, 18(5), pp. 668-680. doi: http://dx.doi.org/10.33225/jbse/19.18.668

Azevedo, A. C.; Vieira, L. P.; Aguiar, C. E.; Santos, A. C. F. (2014), “Teaching light reflection and refraction to the blind", Physics Education, 50(1), pp. 1-5. doi: http://dx.doi.org/10.1088/0031-9120/50/1/15

Barell, John F. (2007), Problem-based Learning: An Inquiry Approach, Thousand Oaks, CA: Corwin Press.

Baughman Jr, James; Zollman, Dean (1977), "Physics labs for the blind", The Physics Teacher, 15(6), pp. 339-342. doi: http://dx.doi.org/10.1119/1.2339668

Beck-Winchatz, Bernhard; Ostro, Steven J. (2004), "Using asteroid scale models in space science education for blind and visually impaired students", Astronomy Education Review, 2(2), pp. 118-126. doi: http://dx.doi.org/10.3847/ AER2003018

Beck-Winchatz, Bernhard; Riccobono, Mark A. (2008), “Advancing participation of blind students in Science, Technology, Engineering and Math", Advances in Space Research, 42, pp. 1855-1858. doi: http://dx.doi.org/10.1016/j. asr.2007.05.080

Briten, Elizabeth; Allen, Michael (2018), Addressing Children Misconceptions through Talk. Unlocking Speaking and Listening. Developing Spoken Language in the Primary Classroom. Routledge, England.

Brvar, Roman (2000), Geografija nekoliko drugače, Ljubljana: National Education Institute Slovenia.

Brvar, Roman (2010), Dotik znanja: Slepi in slabovidni učenci v inkluzivni šoli, Ljubljana: Modrijan.

Cain, Melissa; Fanshawe, Melissa (2019), "Opening eyes to vision impairment: Inclusion is just another way of seeing”, in: Carter, Susan (ed.), Opening Eyes onto Inclusion and Diversity, Toowoomba, Australia: USQ Pressbooks, pp. 239-288.

Conezio, Kathleen; French, Lucia (2002), "Science in the preschool classroom", Young Children, 57(5), pp. 12-18.

De Oliveira, Felipe S., Nascimento, A. S. D.; Bianconi, M. L. (2017), “Teaching enzyme activity to the visual impaired and blind students", Technologies, 5(3), pp. 52. doi: http://dx.doi.org/10.3390/technologies5030052 
Dion, Matthew; Hoffmann, Karen; Matter, Amy (2000), Teacher's Manual for Adapting Science Experiments for Blind and Visually Impaired Students, Christchurch, New Zealand: Elmwood Resource Centre.

Ediyanto, Ediyanto; Kawai, Norimune. (2019), "Science learning for students with visually impaired: A literature review", Journal of Physics: Conference Series (Vol. 1227, No. 1, p. 012035). IOP Publishing. doi: http://dx.doi. org/10.1088/1742-6596/1227/1/012035

Erwin, Elizabeth J., Perkins, Tiffany S., Ayala, Jennifer, Fine, Michelle; Rubin, Ellen (2001), "You don't have to be sighted to be a scientist, do you? Issues and outcomes in science education", Journal of Visual Impairment and Blindness, 59(6), pp. 338-352. doi: https://doi.org/10.1177/0145482X0109500603

Eshach, Haim; Fried, Michael N. (2005), "Should science be taught in early childhood?", Journal of Science Education and Technology, 14(3), pp. 315-336. doi: http://dx.doi.org/10.1007/s10956-005-7198-9

Eškirović, Branka (2015), Vizuelno funkcionisanje i slabovidost, Beograd: Univerzitet u Beogradu-Fakultet za specijalnu edukaciju i rehabilitaciju.

Ferjan, Tamara (2005), "Thoughts on constructivist oriented lessons", Didactica slovenica - Pedagoška obzorja, 20(3-4), pp. 147-150.

Florjančič, Stane, Gerbec, Ivo; Hafnar, Mirjana (2003), Instructions for Educational Programs with Modified Implementation and Additional Professional Assistance for Primary Schools, Ljubljana: Republic of Slovenia, Ministry of Education.

Fraser, William John; Maguvhe, Mbulaheni Obert (2008), "Teaching life sciences to blind and visually impaired learners", Journal of Biological Education, 42(2), pp. 84-89. doi: http://dx.doi.org/10.1080/00219266.2008.9656116

Gil-Pérez, Daniel; Guisasola, Jenaro; Moreno, Antonio; Cachapuz, Antonio; Pessoa De Carvalho, Anna M.; Martínez Torregrosa, Joaquín; Salinas, Julia; Valdés, Pablo; González, Eduardo; Gené Duch, Anna; Dumas-Carré, Andrée; Tricárico, Hugo; Gallego, Rómulo (2002), "Defending constructivism in science education", Science and Education, 11, pp. 557-571. doi: http:// dx.doi.org/10.1023/A:1019639319987

Hadzigeorgiou, Yannis (2002), "A study of the development of the concept of mechanical stability in preschool children", Research in Science Education, 32(3), pp. 373-391. doi: http://dx.doi.org/10.1023/A:1020801426075

Hasse, Maren; Nicolajsen, Niels; Stirrett, Linda; Svekla, Richard (2011), Accessible Science Labs: A Resource with Experiments for Junior and Senior High Students who are Blind or Visually Impaired. The Vision Resource Centre. Available at: http://www.vision.alberta.ca/media/95794/accessible\%20science $\% 20$ labs $\% 20$ resource $\% 20$ book $\% 20 \% 28$ pages $\% 201-20 \% 29$.pdf [22 July 2020].

Horzum, Tugba (2018), "Preservice mathematics teachers' perceptions about visually impaired persons", International Journal of Progressive Education, 14(4), pp. 126-143. doi: http://dx.doi.org/10.29329/ijpe.2018.154.10 
Ivanuš Grmek, Milena; Čagran, Branka; Sadek, Lidija (2009), Didactic Approaches in Teaching the Subject "Environmental Education" in the Third Grade of Primary School, Scientific reports of Educational Research Institute of Slovenia, Ljubljana: Educational Research Institute.

Jones, Gail M.; Minogue, James; Oppewal, Tom; Cook, Michelle P.; Broadwell, Bethany (2006), "Visualizing without vision at the microscale: Students with visual impairments explore cells with touch", Journal of Science Education and Technology, 15(5-6), pp. 345-351. doi: http://dx.doi.org/10.1007/ $\underline{\text { s10956-006-9022-6 }}$

Katalinič, Dane (2010), First Steps in Natural Sciences, Odranci: Mizarstvo Antolin, d.o.o.

Kavkler, Marija (2005), "Learning science for students with special needs", in: Naji, M.; Labernik Z. (eds.), Science for Children with Special Needs: Proceedings, Ljubljana: National Education Institute Slovenia, pp. 20-22.

Kermauner, Aksinja (2004), Tipna slikanica za slepe, Graduation thesis, Ljubljana: Faculty of Education.

Kermauner, Aksinja (2011), "Prvoosebna fenomenološka študija samogenerirane slepote", Journal of Elementary Education, 4(1-2), pp. 81-94.

Kermauner, Aksinja (2014a), “Audio-haptic-virtual Mona Lisa (The Blind and Painting)", Journal for the Critique of Science, Imagination, and New Anthropology, 42(255), pp. 173-181.

Kermauner, Aksinja (2014b), "Umetnost za vse", Journal of Elementary Education, 7(3-4), pp. 17-32.

Kermauner, Aksinja; Plazar, Janja (2019), Prilagojeni pripomočki in metode pri vzgojno-izobraževalnem delu z otroki s posebnimi potrebami, Nova Gorica: EDUCA izobraževanje.

Kizilaslan, Aydin; Sozbilir, Mustafa; Zorluoglu, Seraceddin Levent (2019), "Making science accessible to students with visual impairments: Insulation-materials investigation", Journal of Chemical Education, 96(7), pp. 1383-1388. doi: http://dx.doi.org/10.1021/acs.jchemed.8b00772

Kolenc, Janez (2005), "Science for children with special needs", in: Naji, M.; Labernik Z. (eds.), Science for Children with Special Needs: Proceedings, Ljubljana: National Education Institute Slovenia, pp. 9-14.

Koomen, Michele; Kahn, Sami; Atchison, Christopher L.; Wild, Tiffany A. (eds.) (2018), Towards Inclusion of All Learners through Science Teacher Education, BRILL.

Krnel, Dušan (2008), "Nature", in: Marjanovič Umek, Ljubica, A Child in the Kindergarten. Kindergarten Curriculum Handbook, Maribor: Založba Obzorja, pp. $157-175$.

Kumar, David D., Ramasamy, Rangasamy; Stefanich, Greg P. (2001), "Science for students with visual impairments: Teaching suggestions and policy implications for secondary educators", The Electronic Journal for Research in Science 
and Mathematics Education, 5 (3). Available at: http://ejse.southwestern.edu/ article/view/7658/5425 [15 October 2020]

Mantzicopoulos, Panayota; Patrick, Hellen; Samarapungavan, Ala (2008), "Young children's motivational beliefs about learning science", Early Childhood Research Quarterly, 23(3), pp. 378-394. doi: http://dx.doi.org/10.1016/j.ecresq.2008.04.001

Marentič Požarnik, Barica (2003), "Successfully trained teachers are the basis for the successful integration of students with special needs", Journal of Contemporary Educational Studies, 54, pp. 104-113.

Marentič Požarnik, Barica (2020), Psihologija učenja in pouka, Ljubljana, DZS.

Maroney, Sharon A.; Finson, Kevin D.; Beaver, John B.; Jensen, Mary M. (2003), "Preparing for successful inquiry in inclusive science classroom", Teaching Exceptional Children, 36(1), pp. 18-25. doi: http://dx.doi. org/10.1177/004005990303600102

Martin, Ralph; Sexton, Colleen; Gerlovich, Jack (2014), Teaching Science for All Children, Edinburg Gate, Essex: Pearson Education Limited.

Mastropieri, Margo A.; Scruggs, Thomas E. (1992), "Science for students with disabilities", Review of Educational Research, 62(4), pp. 377-411. doi: http:// dx.doi.org/10.3102/00346543062004377

Mastropieri, Margo A.; Scruggs, Thomas E.; Boon, Richard; Butcher Carter, Karen (2001), "Correlates of inquiry learning in science: Constructing concepts of density and buoyancy", Remedial and Special Education, 22(3), pp. 130-137. doi: http://dx.doi.org/10.1177/074193250102200301

Milković, Javorka; Šupe, Tanja (2013), Praktične aktivnosti za rad s djecom oštećena vida, Zagreb: Hrvatski savez slijepih.

Mirzaie, Abdullah Rasol; Hamidi, Farideh; Anaraki, Ashraf (2009), "A study on the effect of science activities on fostering creativity in preschool children", Journal of Turkish Science Education, 6(3), pp. 81-90.

Mitchell, William John Thomas (1986), Iconology: Image, Text, Ideology, Chicago - London: The University of Chicago Press.

Mullis, Ina V.; Jenkins, Lynn B. (1988), The Science Report Card: Elements of Risk and Recovery: Trends and Achievement Based on the 1986 National Assessment, Princeton, NJ: Educational Testing Service.

Mulloy, Austin M.; Gevarter, Cindy; Hopkins, Megan; Sutherland, Kevin S.; Ramdoss, Sathiyaprakash (2014), "Assistive technology for students with visual impairments and blindness", Assistive Technologies for People with Diverse Abilities, Springer, New York, NY. pp. 113-156. doi: http://dx.doi. org/10.1007/978-1-4899-8029-8_5

National Eye Institute of the National Institutes of Health, USA (2020), Cerebral Visual Impairment (CVI). Available at: https://www.nei.nih.gov/learn-about-eye-health/eye-conditions-and-diseases/cerebral-visual-impairment-cvi [28 April 2021]. 
Nepomuceno, Gabriella M.; Decker, Debbie M.; Shaw, Julian D.; Boyes, Lee; Tantillo, Dean J.; Wedler, Henry B. (2016), "The value of safety and practicality: Recommendations for training disabled students in the sciences with a focus on blind and visually impaired students in chemistry laboratories", Journal of Chemical Health and Safety, 23(1), pp. 5-11. doi: http://dx.doi.org/10.1021/ acs.chas. $8 \mathrm{~b} 23105$

Norman, Katherine; Caseau, Dana; Stefanich, Greg P. (1998), "Teaching students with disabilities in inclusive science classrooms: Survey results", Science Education, 82(2), pp. 127-146. doi: http://dx.doi.org/10.1002/(SICI)1098-237X(199804)82:2

Okcu, Betül; Mustafa Sozbilir (2019), "Designing a bulb to teach electric circuits to visually impaired students", The Physics Teacher, 57(2), pp. 99-101. doi: http://dx.doi.org/10.1119/1.5088470

Petek, Darija (2012), “Zgodnje učenje in poučevanje naravoslovja z raziskovalnim pristopom (Inquiry-based early science teaching and learning)", Journal of Elementary Education, 5(4), pp. 101-114.

Plazar, Janja (2015), "Učenje naravoslovja za slepe in slabovidne učence" ("Teaching science to blind or partially sighted students"), Journal of Elementary Education, 8(4), pp. 159-176.

Republic of Slovenia, Ministry of education (2011), "Primary school curricula for an adapted educational program with an equivalent educational standard for blind and visually impaired students". Available at: https://www.gov.si/assets/ ministrstva/MIZS/Dokumenti/Izobrazevanje-otrok-s-posebnimi-potrebami/ OS/Predmetnik_os_za slepe in_slabovidne_2014.pdf [13 September 2020]

Reynaga-Peña, Cristina Gehibie; del Carmen López-Suero, Carolina (2020), "Strategies and technology aids for teaching science to blind and visually impaired students", in: User-Centered Software Development for the Blind and Visually Impaired: Emerging Research and Opportunities, IGI Global, pp. 26-37. doi: http://dx.doi.org/10.4018/978-1-5225-8539-8.ch002

Ricker, K. S.; Rodgers, N. C. (1981), "Modifying instructional materials for use with visually impaired students", The American Biology Teacher, 43(9), pp. 490-501. doi: http://dx.doi.org/10.2307/4447369

Rosenblum, L. Penny; Cheng, Li; Beal, Carole R. (2018), "Teachers of students with visual impairments share experiences and advice for supporting students in understanding graphics", Journal of Visual Impairment and Blindness, 112(5), pp. 475-487. doi: http://dx.doi.org/10.1177/0145482X1811200505

Rosenblum, Penny L.; Ristvey, John; Hospitál, Laura (2019), "Supporting elementary school students with visual impairments in science classes", Journal of Visual Impairment and Blindness, 113(1), pp. 81-88. doi: http://dx.doi.or$\mathrm{g} / 10.1177 / 0145482 \mathrm{X} 19833801$

Rule, Audrey C.; Stefanich, Greg P.; Boody, Robert M.; Peiffer, Belinda (2011), "Impact of adaptive materials on teachers and their students with visual impairments in secondary science and mathematics classes", International Journal of Science Education, 33(6), pp. 865-887. doi: http://dx.doi.org/10.1080/095 $\underline{00693.2010 .506619}$ 
Saçkes, Mesut; Trundle, Kathy C.; Bell, Randy. L.; O’Connell, Ann A. (2011), "The influence of early science experience in kindergarten on children's immediate and later science achievement: Evidence from the early childhood longitudinal study", Journal of Research in Science Teaching, 48(2), pp. 217-235. doi: http://dx.doi.org/10.1002/tea.20395

Sahin, Mehmet; Yorek, Nurettin (2009), "Teaching science to visually impaired students: A small-scale qualitative study", US-China Education Review, 6(4), pp. 19-26.

Skribe-Dimec, Darja (2009), "Motivacija kot pomembna vez med cilji, osrednjim delom in zaključnim delom učne ure pri pouku naravoslovja", in: Medved Udovič, Vida; Cotič, Mara; Cencič, Majda (eds.), Pouk v družbi znanja, Koper: Faculty of Education, pp. 170-182.

Stefanich, Greg (2018), "Book review: Towards inclusion of all learners through science teacher education", Journal of Science Education for Students with Disabilities, 21(1), pp. 40-48. doi: http://dx.doi.org/10.14448/jsesd.10.0005

Stolovitch, Harold D.; Keeps, Erica J. (2014), Senses: What The Research Tells Us About Their Abilities. Available at: http://velvetchainsaw.com/2012/05/23/ your-senses-your-raw-information-learning-portals/ [1 July 2020]

Supalo, Cary A.; Mallouk, Thomas E.; Amorosi, Christeallia; Rankel, Lillian; Wohlers, David H.; Roth, Alan; Greenberg, A. (2007), "Talking tools to assist students who are blind in laboratory courses", Journal of Science Education for Students with Disabilities, 12(1), pp. 27-32.

Štemberger, Tina (2013), "Učiteljeva pripravljenost na inkluzijo", Didactica slovenica-Pedagoška obzorja, 28(3-4), pp. 3-17.

Teke, D.; Sozbilir, M. (2019), “Teaching energy in living systems to a blind student in an inclusive classroom environment", Chemistry Education Research and Practice, 20(4), pp. 890-901. doi: http://dx.doi.org/10.1039/C9RP00002J

Therrien, William J.; Taylor, Jonte C.; Watt, Sarah; Kaldenberg, Erica R. (2014), "Science instruction for students with emotional and behavioural disorders", Remedial and Special Education, 35(1), pp. 15-27. doi: http://dx.doi. org/10.1177/0741932513503557

Trundle, Kathy C. (2010), "Teaching science during the early childhood years", Best Practices and Research Base. National Geographic Learning. Available at: http://ngl.cengage.com/assets/downloads/ngsci pro0000000028/am trundle teach sci early child scl22-0429a.pdf [25 July 2020]

Trundle, Kathy C. (2014), "Teaching young children science”, in: Yasar, Mustafa; Ozgun, Ozkan; Galbraith, Jeanne (eds.), Contemporary Perspectives and Research on Early Childhood Education, Cambridge Scholars Publishing, pp. $126-134$.

Tu, Tsunghui (2006), "Preschool science environment: What is available in a preschool classroom?", Early Childhood Education Journal, 33(4), pp. 245-251. doi: http://dx.doi.org/10.1007/s10643-005-0049-8

Wagner, B. V. (1995), "Measurement for students who are visually impaired", in: Egelston-Dodd, Judy (ed.), Improving Science Instruction for Students with 
Disabilities: Proceedings of a Working Conference on Science for Persons with Disabilities, National Science Foundation, Arlington, VA, pp. 70-76.

Weems, Bruce (1977), "A physical science course for the visually impaired", The Physics Teacher, 15(6), pp.333-338. doi: http://dx.doi.org/10.1119/1.2339667

WHO (World Health Organization) (2021), Blindness and Vision Impairment. Available at: http://www.who.int/mediacentre/factsheets/fs282/en/ [10 April 2021]

Wild, Tiffany A.; Koehler, Karen E. (2017), “Science”, in: Holbrook, Cay; Kamei-Hannan, Cheryl; McCarthy, Tessa (eds.), Foundations of Education: Volume II. Instructional Strategies for Teaching Children and Youths with Visual Impairments, New York, NY: AFB Press, pp. 449-478.

Windelborn, Augden F. (1999), "Doing physics blind”, The Physics Teacher, 37(6), pp. 366-367. doi: http://dx.doi.org/10.1119/1.880322

\title{
NASTAVA IZ PRIRODOSLOVNOG PODRUČJA ZA SLIJEPU DJECU I DJECU S OŠTEĆENJIMA VIDA
}

\author{
Janja Plazar, Cécil J. W. Meulenberg, Aksinja Kermauner
}

Nastava iz prirodoslovnog područja danas se najčešće temelji na principima konstruktivizma prema kojima djeca trebaju biti aktivni sudionici procesa učenja $i$ izgrađivati svoje znanje na temelju iskustva. Metode i sredstva korištena u nastavi prirodoslovnog područja moraju biti prilagođeni perceptivnim potrebama slijepe djece $i$ djece s oštećenjima vida kako bi im se omogućilo aktivno sudjelovanje u procesu učenja. Cilj ovoga rada je opisati posljednje spoznaje o aktivnom $i$ istraživačkom učenju slijepe djece $i$ djece $s$ oštećenjima vida u nastavi prirodoslovnog područja te otkloniti postojeće zablude. Nadalje, rad predstavlja recentna istraživanja koja ukazuju na prilagođene uspješne $i$ visokokvalitetne odgojno-obrazovne pristupe i metode. S obzirom na navedeno, sadržaj rada bit će od koristi nastavnicima iz prirodoslovnog područja, kao i istraživačima inkluzivnih učionica.

Ključne riječi: aktivno učenje, prilagođeni odgojno-obrazovni alati, sljepoća, inkluzija, oštećenja vida 